\title{
Deep Water Cooled ORC for Offshore Floating Oil Platform Applications
}

\author{
C. G. F. do Val ${ }^{1}$, J. A. M. Silva²*, S. Oliveira Jr. ${ }^{3}$ \\ ${ }^{1,2}$ Mechanical Engineering Department, Polytechnic School, Federal University of Bahia, Salvador, Brazil \\ ${ }^{3}$ Mechanical Engineering Department, Polytechnic School, University of São Paulo, São Paulo, Brazil \\ E-mail: ${ }^{1}$ caiodoval1@ @otmail.com, ${ }^{2 j u l i o . s i l v a @ u f b a . b r, ~}{ }^{3}$ soj@usp.br
}

Received 23 October 2016, Revised 29 July 2017, Accepted 05 October 2017

\begin{abstract}
Due to global warming, environmental pollution and cost reduction, increasing efficiency of electricity conversion has become a key issue for the offshore market. This paper proposes an Organic Rankine Cycle (ORC), which uses heat waste from exhaust gases of an FPSO (Floating, Production, Storage and Offloading unit) as heating source, and deep ocean water as cooling source. A genetic algorithm optimization was conducted targeting maximization of net power output, by taking in to consideration of 23 working fluids. Expander inlet temperature and pressure were set as independent variables. The analysis encompasses subcritical or supercritical conditions and recuperation was included in a second version of the system as an option. The first configuration presented ethanol as optimal fluid, followed by toluene and the second configuration indicated cyclohexane followed by ethanol. Use of recuperation, when feasible, increased power output specially for cycles operating with dry and isentropic fluids, presenting an average contribution of $22.7 \%$. Net power and efficiency results from ORC using deep sea water in condenser were presented and compared with ORC using shallow ocean water as cooling source and with Carnot efficiency operating under the same temperatures. Use of deep water raised net power output by $23.3 \%$ (cyclohexane recuperative ORC) and $12.5 \%$ (ethanol non-recuperative ORC) for the optimal configurations.
\end{abstract}

Keywords: ORC; deep water; FPSO; power generation.

\section{Introduction}

The increase in energy demand over the next two decades poses a challenge for the oil and gas sector, which is already one of the major contributors of $\mathrm{CO} 2$ emissions. In Brazil, for instance, oil, gas and coal industry was responsible for $37 \%$ of greenhouse gas emission in 2012 [1]. In Norway, oil and gas extraction represented about $28 \%$ of those emissions in 2014 [2]. The search for more efficient processes is important not only due to environmental issues, but also because of cost reductions, once oil production and refining consume nearly $10 \%$ of the produced oil [3].

A considerable number of studies [4-9] developed researches on efficiency evaluation for offshore oil extraction and its related processes. Nguyen et al. [4] suggested a component-by-component exergy efficiency formulation for offshore oil and gas processing. De Oliveira \& Van Hombeeck [5] studied exergetic efficiency and losses of a Brazilian offshore platform. Nguyen et al. [6] pinpointed exergy losses of an offshore platform for three stages of an oil field, while an exergy accounting was performed for six cases corresponding to different reservoir fluid compositions by Nguyen et al. [7]. Voldsund et al. [8] identified exergy losses of four platforms located in the North Sea. Voldsund et al. [9] applied exergy analysis on a real production day of an offshore platform. Most of the studies [4, 6-8] stressed the importance of good use of the waste heat contained in the exhaust gases.

A possible use for the waste heat is electricity generation through an ORC (Organic Rankine Cycle).
ORCs employ organic fluids instead of water as working fluid. They are usually exploited when a low-grade energy source is available, such as waste heat, solar energy, ocean thermal energy, geothermal energy and biomass, providing better results than those from water Rankine cycles. There is an extensive literature about ORCs for waste heat recovery. Particularly, the works of Mazetto et al. [10] and Pierobon et al. [11] performed a genetic algorithm (GA) optimization for ORC recovering waste heat systems. The former targeted maximization of net power output and maximization of power to heat transfer area ratio in a petroleum refinery, whereas the later optimized thermal efficiency, total volume of the system and net present value in an offshore platform. Optimizations portrayed by Mazetto et al. [10] displayed R134a and water as the best fluids - amongst the evaluated ones, while cyclopentane and acetone were considered as optimal working fluids by Mazetto et al. [10]. Yang and Yeh [12] proposed and optimized an ORC for recovering waste heat from a large marine engine. They concluded that R600a would give the highest ratio of net power output to the total heat-transfer area. Yang and Yeh [13] optimized an ORC for marine waste heat recovery through thermo-economic indicators and found R1234yf as the best option. The integration of an ORC in a Brazilian FPSO (Floating, Production, Storage and Offloading unit) was studied by Barrera et al. [14], moreover, the study defends that there is a great potential for generating power from exhaust gases. Some studies [1517] took in consideration the use of supercritical ORC for waste heat recovery. Glover et al [15] simulated an ORC 
operating under supercritical conditions and recovering heat from internal combustion engine. Kosmadakis et al. [16] performed an experimental investigation of an ORC operating at both subcritical and supercritical conditions and using a heat source at $95^{\circ} \mathrm{C}$. Le et al. [17] conducted a performance optimization of supercritical ORCs using a heat source at $150^{\circ} \mathrm{C}$. Desideri et al [18] conducted an experimental comparison between the fluids SES36 and R245fa for low temperature ORC waste heat recovery systems.

Besides its application in waste heat recovery systems, ORC has also been investigated for Ocean Thermal Energy Conversion (OTEC). Ocean thermal energy is solar energy absorbed and stored as heat in the upper layer of the ocean [19]. The water becomes colder as depth increases, and at $800 \mathrm{~m}$ to $1000 \mathrm{~m}$, it reaches temperatures around $4^{\circ} \mathrm{C}$ [20]. OTEC uses those two layers as heating and cooling sources for a heat engine. It works under either an open-cycle or a closed-cycle process [19]. The open-cycle configuration presents lower efficiency, one of the reasons why most OTEC plants operate on the Rankine closed-cycle or its variants [21]. Yuan et al. [22] proposed an absorption OTEC closed cycle, where ammonia-water was the working fluid, achieving $4.17 \%$ thermal efficiency. Yang and Yeh [23] conducted an optimization of the ratio of net power output to the total heat transfer area on an OTEC plant, using ORC, in which R717 performed optimally. Even though OTEC comes out as a low environmental impactful process, the low practical efficiency due to the small temperature gap hampers its deployment [21].

The present work proposes an ORC waste heat recovery in an offshore oil platform. While the heating source for the suggested system is the exhaust gases of an offshore engine, the cooling source is deep seawater as in the closedcycle OTEC. In other words, the system is a combination of two different applications for ORCs, which are not usually studied together in the literature. Expander inlet pressure and temperature were the independent variables, and maximization of net power output was aimed for each one of the tested fluids. A second scenario of the system including recuperation was also studied and all results were compared with conventional ORC using surface water as cooling source in order to analyze the contribution of the utilization of deep seawater to power generation. During any simulation, supercritical conditions are accepted if they provide better results.

\section{Proposed System}

In this section the ORC configurations, thermodynamic equations as well as the applied methodology are described.

\subsection{System Description}

Recuperative ORCs (RORC) and non-recuperative ORCs (NORC) were assessed. Supercritical conditions were allowed for fluids with superior performance in these conditions.

\subsubsection{Non-recuperative ORC}

The first layout of the proposed ORC has two possible configurations shown in Figure 1 with their respective T-s diagrams. The system in Figure 1(a) is a non-recuperative subcritical ORC. Starting the explanation from state 1, the working fluid, at saturated liquid state, is compressed by the pump to the evaporation pressure (state 2), which is in this case lower than the critical one. Then, the working fluid receives reject heat from the exhaust gases, firstly through the economizer, reaching the saturated temperature (state 3). Next, through the evaporator, the fluid becomes saturated vapor (state 4). Finally, if advantageous for power output (which depends on the working fluid), the saturated vapor is super-heated (state 5). From state 5 (or state 4 , in case super-heating is nonexistent) the working fluid is expanded to the condensation pressure (state 6) and then it enters the cooling process. Considering that the fluid leaves the expander as super-heated vapor, a desuperheater is necessary to turn it into saturated vapor (state 7) before entering the condenser. Otherwise, the fluid is sent directly to the condenser from the expander outlet. Both desuperheater and condenser make use of seawater to remove heat from the working fluid. After the condenser, the fluid is again at state 1 .

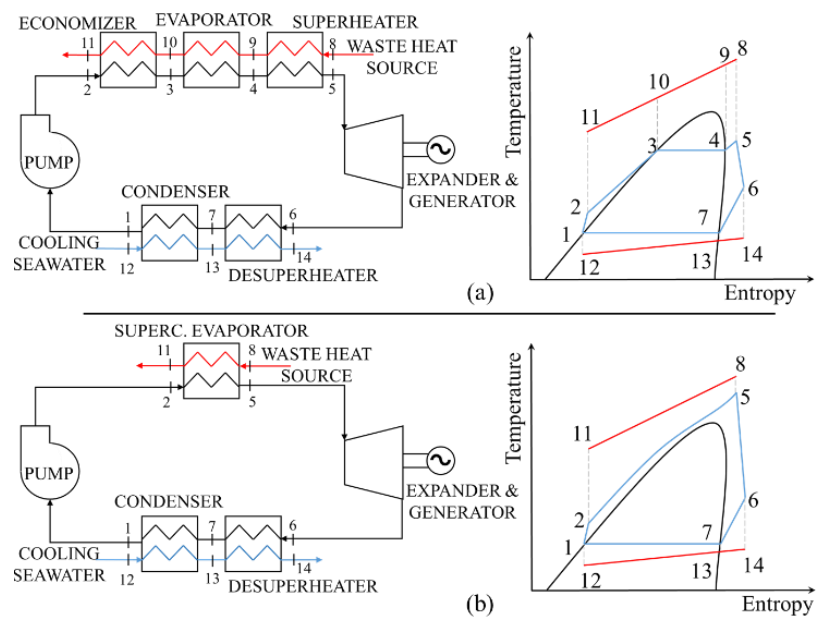

Figure 1. Configuration and T-s diagram of NORC: a) subcritical, b) supercritical.

The supercritical cycle depicted in Figure 1(b) is similar in most aspects to the previously described one. The main difference is the pump outlet pressure. In this case, the pressure is above the critical one, which means that the fluid will not face a gradual evaporation process, thus only one heat exchanger was modelled in the upper part of the cycle. The optimal expander inlet pressure indicated during the simulation is what determinates if each working fluid is operating under subcritical or supercritical configuration.

\subsubsection{Recuperative ORC}

A second layout of the proposed system is represented in Figure 2. In this layout, a recuperator is installed. This equipment allows the flow leaving the expander to transfer heat to the one leaving the pump. The condition for applying this layout is $T_{6}>T_{2}$. In case this condition is not met by a specific working fluid, this layout is not taken in consideration. The purpose of this recuperative process is to recover a fraction of the heat (area 1 in Figure 2) that would originally be lost from the working fluid to seawater.

Once again, the cycle can be either subcritical (Figure 2(a)) or supercritical (Figure 2(b)) depending on the same factors exposed in Section 2.1.1.

For both NORC and RORC at supercritical conditions, it was checked if the expansion process went through the two phase region by comparing the values of specific 
entropy at the saturation line with the specific entropy values between point 5 and 6 (expansion process).

\subsection{Thermodynamic Model}

According to Brandsar [24] the main energy sources for ORCs in offshore applications are gas turbine exhausting gas, gas compressors intercoolers (compression train), and gas or diesel internal combustion engines exhausting gas. Pereira et al. [25] characterized Brazilian offshore utilities plants as $50 \%$ based on gas turbines and almost $12 \%$ based on internal combustion engines. The temperature of gas turbine and internal combustion engine exhausting gases depends whether these gases are used for petroleum heating or not. Thus, the exhausting temperature also varies with the FPSO production curve as well as its required heat load. The heat source considered in this work is the exhausting gas of an aeroderivative gas turbine $(64 \mathrm{~kg} / \mathrm{s})$ after oil heating $\left(330^{\circ} \mathrm{C}\right)$. This heat source temperature is close to the value presented by Pierobon et al. [26] $\left(335^{\circ} \mathrm{C}\right)$ for the same application. In order to avoid uneconomical configurations the minimal temperature allowed for the exhausting gas was $105^{\circ} \mathrm{C}$.

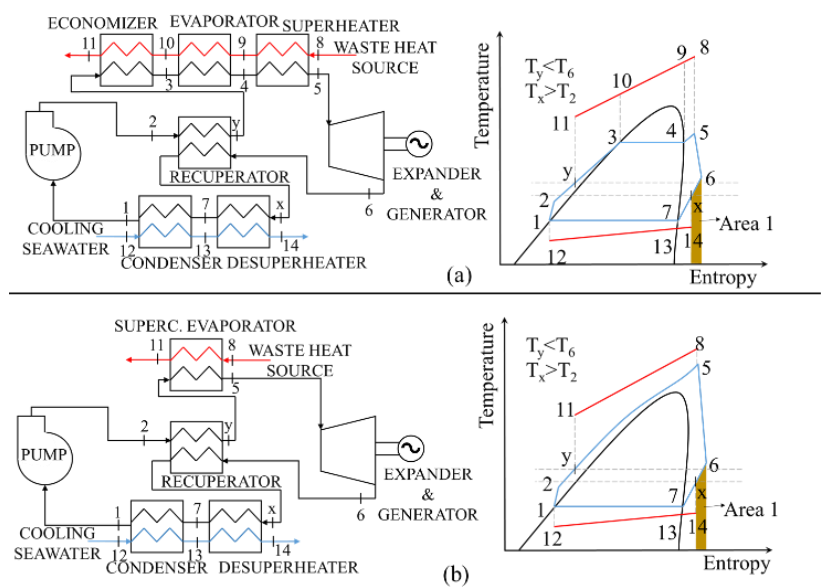

Figure. 2. Configuration and T-s diagram of RORC: a) subcritical, b) supercritical.

Most of new Brazilian FPSOs are been used in deep water exploration [27]. The water temperature drops with depth down to $4^{\circ} \mathrm{C}$ at $1000 \mathrm{~m}$ [28]. Thus, this cold temperature reservoir will be used to provide extra power in the proposed system. Since the deep seawater will be rejected at sea level, the required cooling water pump head is for pressure loss in pipes and heat exchanger only [29]. In this model, it is considered the power to overcome the pressure drop in the cooling water pipe, as it affects the comparison between deep and shallow water operations.

The components of the proposed system are modelled at steady state. General assumptions are: 1) the equipment as well as pipes do not lose heat to environment, 2) potential and kinetic energy variations are neglected, 3) pressure drops in pipes and heat exchangers are neglected (except deep cooling water pipe). Table 1 gives the equipment parameters for the simulations together with cooling and heating specifications.

Isentropic efficiency definitions for the expander and pump are given in Eqs. (1) and (2), respectively.

$$
\eta_{\mathrm{t}, \mathrm{ise}}=\frac{h_{5}-h_{6}}{h_{5}-h_{6, \text { ise }}}
$$

$\eta_{\mathrm{p}, \mathrm{ise}}=\frac{h_{1}-h_{2, \text { ise }}}{h_{1}-h_{2}}$

Eqs. (3) and (4) show energy balance for expander and pump, respectively.

$$
\begin{aligned}
& \dot{W}_{t}=\dot{m}_{w f} \cdot\left(h_{5}-h_{6}\right) \\
& \dot{W}_{p}=\dot{m}_{w f} \cdot\left(h_{2}-h_{1}\right)
\end{aligned}
$$

Table 1. System Specifications.

\begin{tabular}{ll}
\hline Parameter & Value \\
\hline Expander isentropic efficiency $\left(\eta_{\mathrm{t}, \text { ise }}\right)$ & $80.0 \%$ \\
Pump Isentropic efficiency $\left(\eta_{\mathrm{p}, \text { ise }}\right)$ & $75.0 \%$ \\
Recuperator effectiveness $\left(\varepsilon_{\mathrm{r}}\right)$ & $85.0 \%$ \\
Pinch temperature difference at condenser & $10.0^{\circ} \mathrm{C}$ \\
Minimum pinch temperature difference at & $10.0^{\circ} \mathrm{C}$ \\
evaporator & $330^{\circ} \mathrm{C}$ \\
Exhaust gases temperature at state $8\left(T_{8}\right)$ & $105^{\circ} \mathrm{C}$ \\
Minimum exhaust gases temperature at state 11 & $64.0 \mathrm{~kg} / \mathrm{s}$ \\
(Ti1) & $1.20 \mathrm{~kJ} /(\mathrm{kg} \cdot \mathrm{K})$ \\
Exhaust gases mass flow rate $\left(\dot{m}_{\mathrm{eg}}\right)$ & $5.00{ }^{\circ} \mathrm{C}$ \\
Exhaust gases average specific heat $\left(\mathrm{c}_{\mathrm{P}, \mathrm{eg}}\right)$ & $18.0{ }^{\circ} \mathrm{C}$ \\
Deep seawater temperature at state $12\left(T_{12, \mathrm{dsw}}\right)$ & $32.0{ }^{\circ} \mathrm{C}$ \\
Condensation temperature when using deep & $45.0{ }^{\circ} \mathrm{C}$ \\
seawater $\left(T_{7, \mathrm{dsw}}\right)$ & 0.01362 \\
Shallow seawater temperature at state $12\left(T_{12, \mathrm{ssw}}\right)$ & $1000 \mathrm{~m}$ \\
Condensation temperature when using shallow & $1000 \mathrm{~kg} / \mathrm{m}^{3}$ \\
seawater $\left(T_{7, \mathrm{ssw}}\right)$ & $1.200 \mathrm{~m} / \mathrm{s}$ \\
Cooling water pipe friction factor $(\mathrm{f})$ & $9.807 \mathrm{~m} / \mathrm{s}^{2}$ \\
Cooling deep water pipe length $(\mathrm{L})$ & \\
Density of cooling water $(\rho)$ & \\
Cooling water flow velocity $(\mathrm{v})$ & \\
Gravitational acceleration &
\end{tabular}

Eqs. (5), (6), (7) and (8) give the energy balance of the economizer, evaporator, super-heater and supercritical evaporator.

$$
\begin{aligned}
& \dot{m}_{e g} \cdot \mathrm{c}_{\mathrm{P}, \mathrm{eg}} \cdot\left(T_{11}-T_{10}\right)=\dot{m}_{w f} \cdot\left(h_{3}-h_{2}\right) \\
& \dot{m}_{e g} \cdot \mathrm{c}_{\mathrm{P}, \mathrm{eg}} \cdot\left(T_{10}-T_{9}\right)=\dot{m}_{w f} \cdot\left(h_{4}-h_{3}\right) \\
& \dot{m}_{e g} \cdot \mathrm{c}_{\mathrm{P}, \mathrm{eg}} \cdot\left(T_{9}-T_{8}\right)=\dot{m}_{w f} \cdot\left(h_{5}-h_{4}\right) \\
& \dot{m}_{e g} \cdot \mathrm{c}_{\mathrm{P}, \mathrm{eg}} \cdot\left(T_{11}-T_{8}\right)=\dot{m}_{w f} \cdot\left(h_{5}-h_{2}\right)
\end{aligned}
$$

Energy balance for desuperheater and condenser are given in Eqs. (9) and (10).

$$
\begin{aligned}
& \dot{m}_{c w} \cdot \mathrm{c}_{\mathrm{P}, \mathrm{cw}} \cdot\left(T_{14}-T_{13}\right)=\dot{m}_{w f} \cdot\left(h_{7}-h_{6}\right) \\
& \dot{m}_{c w} \cdot \mathrm{c}_{\mathrm{P}, \mathrm{cw}} \cdot\left(T_{13}-T_{12}\right)=\dot{m}_{w f} \cdot\left(h_{1}-h_{7}\right)
\end{aligned}
$$

Eq. (11) shows effectiveness definition for heat exchanger applied to the recuperator. Energy balance for this equipment is shown in Eq. (12).

$$
\begin{aligned}
& \varepsilon_{\mathrm{r}}=\frac{T_{y}-T_{2}}{T_{6}-T_{2}} \\
& h_{y}-h_{2}=h_{6}-h_{x}
\end{aligned}
$$


Definition of degrees of superheat is given in Eq. (13). Thus, it is directly dependent on the optimized variable $T_{5}$.

$$
\Delta T_{\text {sup }}=T_{5}-T_{4}
$$

Head pressure loss $\left(H_{l}\right)$ for cooling water pipe is given by Eq. (14). The pipe diameter D is calculated using Eq. (15). The value of $v$ was adopted according to commercial values [29] (see Table 1). The friction factor, $f$, was calculated using Colebrook equation. Eq. (16) gives the power consumed by cooling water pump using deep water $\left(\dot{W}_{p, c w}\right)$.

$$
\begin{aligned}
& H_{l}=\mathrm{f} \cdot \frac{L}{D} \cdot \frac{v^{2}}{2 \mathrm{~g}} \\
& D=\sqrt{\frac{4 \cdot \dot{m}_{c w}}{V \cdot \pi \cdot \rho_{\text {water }}}} \\
& \dot{W}_{p, c w}=\frac{\dot{m}_{c w} \cdot \mathrm{g} \cdot H_{l}}{\eta_{\mathrm{p}, \text { ise }}}
\end{aligned}
$$

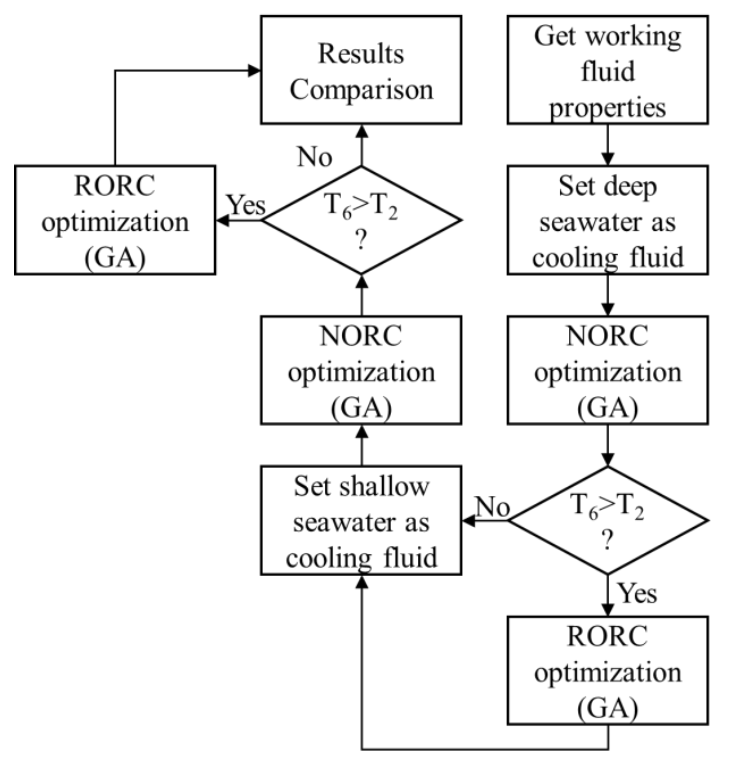

Figure 3. Simulation and optimization flowsheet.

Heat transferred from the exhaust gases Q $\mathrm{h}$ is calculated by Eq. (17). Finally, net power $\dot{\mathrm{W}}_{\text {net }}$ and cycle efficiency $\eta_{\text {tot }}$ are given by Eqs. (18) and (19). It is important to remember that the consumed power due to the cooling water pump losses is only taken in consideration for deep water cooled systems, as earlier explained in this section.

$\dot{Q}_{h}=\dot{m}_{e g} \cdot \mathrm{c}_{\mathrm{P}, \mathrm{eg}} \cdot\left(T_{11}-T_{8}\right)$

$\dot{W}_{n e t}=\dot{W}_{t}-\dot{W}_{p}-\dot{W}_{p, c w}$

$\eta_{\text {tot }}=\frac{\dot{W}_{n e t}}{\dot{Q}_{h}}$

\subsection{Methodology}

In this work, 23 organic working fluids were considered for the proposed system. The selected fluids do not include fluids prohibited by Kyoto or Montreal protocols and are the same used by Mazetto et al. [10]. The steps described in Figure 3 were applied to each of those fluids. The layouts described in 2.1.1 and 2.1.2 (whenever $T_{6}$ is higher than $T_{2}$ ) were simulated and optimized, firstly using deep seawater as cooling fluid, and then using shallow seawater for the same purpose. This methodology was repeated for each one of the 23 considered fluids.

Table 2. Working Fluids Properties.

\begin{tabular}{llll}
\hline Substance & Type & $T_{\text {crit }}\left({ }^{\circ} \mathrm{C}\right)$ & $P_{\text {crit }}(\mathrm{kPa})$ \\
\hline Benzene & Dry & 289 & 4894 \\
Isobutane & Dry & 135 & 3640 \\
n-Butane & Dry & 152 & 3796 \\
n-Decane & Dry & 345 & 2103 \\
n-Dodecane & Dry & 385 & 1817 \\
n-Heptane & Dry & 267 & 2727 \\
n-Hexane & Dry & 235 & 3058 \\
n-Nonane & Dry & 321 & 2281 \\
n-Octane & Dry & 296 & 2497 \\
n-Pentane & Dry & 197 & 3364 \\
Isopentane & Dry & 187 & 3370 \\
Cyclohexane & Isentropic & 281 & 4081 \\
Toluene & Isentropic & 319 & 4126 \\
R123 & Isentropic & 184 & 3668 \\
R134a & Isentropic & 101 & 4059 \\
R141b & Isentropic & 204 & 4249 \\
R142b & Isentropic & 137 & 4055 \\
R245fa & Isentropic & 154 & 3651 \\
R502 & Wet & 82.2 & 4074 \\
R717 & Wet & 132 & 11330 \\
Ethanol & Wet & 242 & 6268 \\
Propane & Wet & 96.7 & 4247 \\
Water & Wet & 374 & 22060 \\
\hline
\end{tabular}

The optimization method is the PIKAIA version of Genetic Algorithm (GA) [30], which consists on a computational model inspired by the Theory of Evolution with efficient means of searching for the global optima. The independent variables are expander inlet pressure $P_{5}$ and temperature $T_{5}$, while objective function is to maximize net power $\dot{W}_{n e t}$ for all optimizations in Figure 3. $P_{5}$ and $T_{5}$ are selected through the GA method, where some combinations of these variables are chosen (a generation) and the output is evaluated. The process is repeated, modifying the newer generations according to the mutation rate until the global optima is found. Boundaries for those variables are also set in order to avoid unrealistic values $\left(T_{5}\right.$ greater than $T_{8}$, for instance).

Simulations were conducted on software EES [31]. Table 2 gives the list of considered working fluids and their properties taken from the software library. All properties used during simulations were taken from this same library.

\section{Results}

In this section, the results are presented and discussed. In section 3.1, the outputs from the configurations with and without recuperation are analyzed and compared between themselves. In section 3.2 those configurations are compared to their relative shallow water cooled versions.

\subsection{Deep Seawater Cooled System}

Optimal values for the independent variables $\left(T_{5}\right.$ and $\left.P_{5}\right)$ as well as working fluid mass flow rate $\left(\dot{m}_{w f}\right)$, degrees of superheat $\left(\Delta T_{\text {sup }}\right)$ and expander inlet pressure condition are 
given in Tables 3 and 4, for NORC and RORC respectively, operating with deep seawater as cooling fluid.

Table 3. Properties of optimized NORC cooled by deep seawater.

\begin{tabular}{|c|c|c|c|c|c|}
\hline Substance & $\begin{array}{l}T_{5} \\
\left({ }^{\circ} \mathrm{C}\right)\end{array}$ & $\begin{array}{l}P_{5} \\
(\mathrm{kPa})\end{array}$ & $\begin{array}{l}\dot{m}_{w f} \\
(\mathrm{~kg} / \mathrm{s})\end{array}$ & $\begin{array}{l}\Delta T_{\text {sup }} \\
\left({ }^{\circ} \mathrm{C}\right)\end{array}$ & Cond. \\
\hline Benzene & 254 & 2005 & 23.3 & 32.0 & Subcrit. \\
\hline Isobutane & 325 & 25600 & 20.3 & - & Superc. \\
\hline n-Butane & 325 & 24020 & 19.9 & - & Superc. \\
\hline n-Decane & 269 & 694.3 & 19.8 & 0 & Subcrit. \\
\hline n-Dodecane & 263 & 274.9 & 19.8 & 0 & Subcrit. \\
\hline n-Heptane & 325 & 8580 & 19.9 & - & Superc. \\
\hline n-Hexane & 325 & 12200 & 19.9 & - & Superc. \\
\hline n-Nonane & 276 & 1201 & 19.7 & 0 & Subcrit. \\
\hline n-Octane & 325 & 5661 & 19.8 & - & Superc. \\
\hline n-Pentane & 325 & 17000 & 19.9 & - & Superc. \\
\hline Isopentane & 325 & 21460 & 20.1 & - & Superc. \\
\hline Cyclohexane & 325 & 7372 & 21.1 & - & Superc. \\
\hline Toluene & 245 & 1536 & 24.2 & 0 & Subcrit. \\
\hline R123 & 325 & 17670 & 48.2 & - & Superc. \\
\hline R134a & 325 & 35200 & 41.5 & - & Superc. \\
\hline $\mathrm{R} 141 \mathrm{~b}$ & 314 & 3999 & 36.1 & 114 & Subcrit. \\
\hline $\mathrm{R} 142 \mathrm{~b}$ & 325 & 22680 & 40.7 & - & Superc. \\
\hline R245fa & 325 & 25340 & 39.6 & - & Superc. \\
\hline R502 & 232 & 3945 & 58.9 & 151 & Subcrit. \\
\hline R717 & 325 & $2998 \cdot 10$ & 10.6 & - & Superc. \\
\hline Ethanol & 325 & 8621 & 12.7 & - & Superc. \\
\hline Propane & 325 & $3235 \cdot 10$ & 20.3 & - & Superc. \\
\hline Water & 325 & 485 & 5.24 & 174 & Subcrit. \\
\hline
\end{tabular}

Most of the substances reached supercritical condition. This was expected when relating the critical properties on Table 2 to the temperature of the exhaust gases, which is high compared to most of the critical temperatures. From a thermodynamic point of view, supercritical ORC has the advantage (over subcritical ORC) of better matching the heating source cooling curve and working fluid heating curve (closer curves) [32], since there is no horizontal evaporation step in boiler temperature profile. Therefore, it may lead to higher efficiency [33] as noted in most of the tested fluids. However, this configuration of ORC presents challenges to overcome, i.e. high pressure required and high pressure ratio in turbine (which affects selection of equipment material), supercritical heat transfer and the uncertainty of working fluid properties in the supercritical region [17].

Sixteen fluids presented the highest temperature $T_{5}$ allowed in the simulation $\left(325^{\circ} \mathrm{C}\right)$ for the NORC system and only two fluids for the RORC. In general, recuperation led to a reduction of the optimal pressure $P_{5}$ and $T_{5}$. This is positive from the equipment cost point of view, once lower pressure and temperature requires less robust material. On the other hand, recuperation allowed a higher mass flow rate $\dot{m}_{w f}$. This means that, even with the expander inlet pressure and temperature decreasing, the absolute power produced by this equipment can increase due to the extra mass flow rate of working fluid.

Table 4. Properties of optimized RORC cooled by deep seawater.

\begin{tabular}{llllll}
\hline Substance & $T_{5}$ & $P_{5}$ & $\dot{m}_{w f}$ & $\Delta T_{\text {sup }}$ & Cond.
\end{tabular}

\begin{tabular}{llllll} 
& $\left({ }^{\circ} \mathrm{C}\right)$ & $(\mathrm{kPa})$ & $(\mathrm{kg} / \mathrm{s})$ & $\left({ }^{\circ} \mathrm{C}\right)$ & \\
\hline Benzene & 239 & 2552 & 27.6 & 0 & Subcrit.
\end{tabular}

$\begin{array}{llllll}\text { Isobutane } & 255 & 12890 & 34.0 & - & \text { Superc. }\end{array}$

$\begin{array}{llllll}\text { n-Butane } & 267 & 13030 & 31.0 & - & \text { Superc. }\end{array}$

n-Decane $237 \quad 402.0 \quad 27.6 \quad 0 \quad$ Subcrit.

n-Dodecane $231 \quad 141.5 \quad 28.0 \quad 0 \quad$ Subcrit.

n-Heptane $277 \quad 3717 \quad 30.9 \quad$ - $\quad$ Superc.

n-Hexane $2715281 \quad 30.9 \quad-\quad$ Superc.

n-Nonane $246 \quad 753.5 \quad 27.1 \quad 0 \quad$ Subcrit.

n-Octane $296 \quad 4000 \quad 28.7 \quad$ - $\quad$ Superc.

n-Pentane $271 \quad 8733 \quad 30.8 \quad$ - $\quad$ Superc.

$\begin{array}{llllll}\text { Isopentane } & 256 & 8608 & 32.9 & - & \text { Superc. }\end{array}$

$\begin{array}{llllll}\text { Cyclohexane } & 303 & 5768 & 28.4 & - & \text { Superc. }\end{array}$

$\begin{array}{llllll}\text { Toluene } & 217 & 992.7 & 29.0 & 0 & \text { Subcrit. }\end{array}$

$\begin{array}{llllll}\mathrm{R} 123 & 308 & 14350 & 63.7 & - & \text { Superc. }\end{array}$

$\begin{array}{llllll}R 134 a & 276 & 19610 & 61.0 & - & \text { Superc. }\end{array}$

$\begin{array}{llllll}\mathrm{R} 141 \mathrm{~b} & 273 & 3947 & 50.6 & 73.0 & \text { Subcrit. }\end{array}$

$\begin{array}{llllll}\mathrm{R} 142 \mathrm{~b} & 303 & 17400 & 54.0 & - & \end{array}$

$\begin{array}{llllll}\mathrm{R} 245 \mathrm{fa} & 280 & 14460 & 58.3 & - & \text { Superc. }\end{array}$

$\begin{array}{llllll}\text { R502 } & 210 & 4001 & 95.3 & 129 & \text { Subcrit. }\end{array}$

$\begin{array}{llllll}\text { R717 } & 325 & 19040 & 10.4 & - & \text { Superc. }\end{array}$

$\begin{array}{llllll}\text { Ethanol } & 325 & 6356 & 12.9 & - & \text { Superc. }\end{array}$

$\begin{array}{llllll}\text { Propane } & 258 & 17470 & 32.4 & - & \end{array}$

Water

Figure 4 indicates optimized values of net power $\dot{W}_{\text {net }}$ for each substance as well as cycle thermal efficiency $\eta_{t o t}$ for both NORC and RORC systems.

Ethanol presented the best results under nonrecuperative process, with net power output of $4926 \mathrm{~kW}$ and $28.51 \%$ of thermal efficiency. Although ethanol becomes very corrosive at high temperatures, it is a very interesting candidate because it is regarded as non-toxic, environmentally friendly and cheap working fluid [34]. Ethanol was followed by toluene (4416kW and $25.56 \%$ ). The poorest performance was from R502 with a net power output of $1796 \mathrm{~kW}(\sim 2.7$ times lower than ethanol) and thermal efficiency of $10.39 \%$. Water achieved net power of $3823 \mathrm{~kW}$ with $23.99 \%$ thermal efficiency

Under recuperative process, cyclohexane performed the best, followed by ethanol. The first presented net power of $5283 \mathrm{~kW}$ with $30.57 \%$ thermal efficiency whereas the second had $5144 \mathrm{~kW}$ and $29.77 \%$. R502 once more presented the lowest net power output and thermal efficiency amongst the RORC simulations $(2684 \mathrm{~kW}$ and $15.53 \%)$. Recuperation was not feasible for water.

Recuperation, when used, always contributed to increasing net power output as well as thermal efficiency with an average relative contribution of $22.7 \%$ for both outputs. Its contribution is not constant, however, as some 


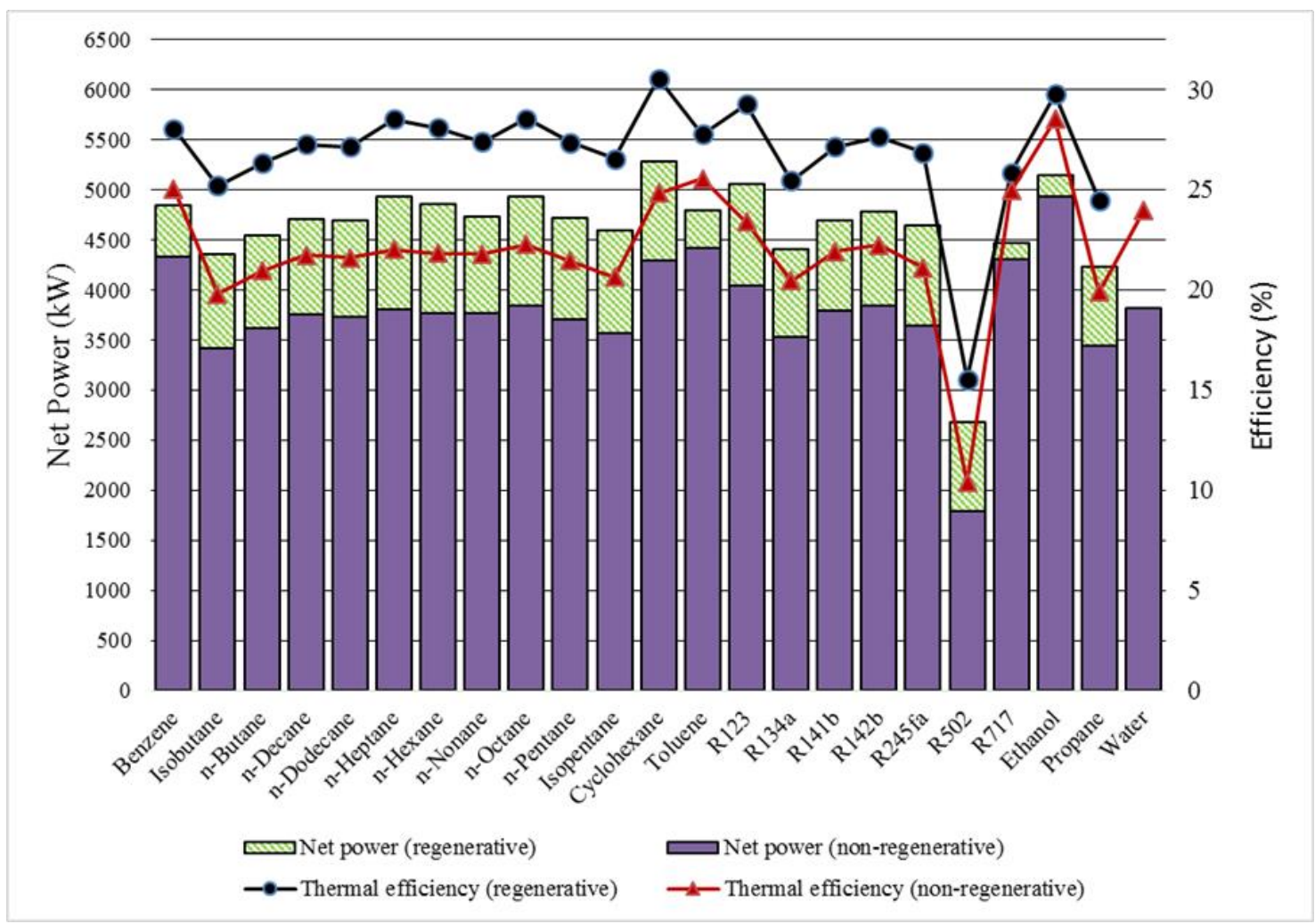

Figure 4. Optimized net power output and thermal efficiency results using deep seawater as cooling fluid.

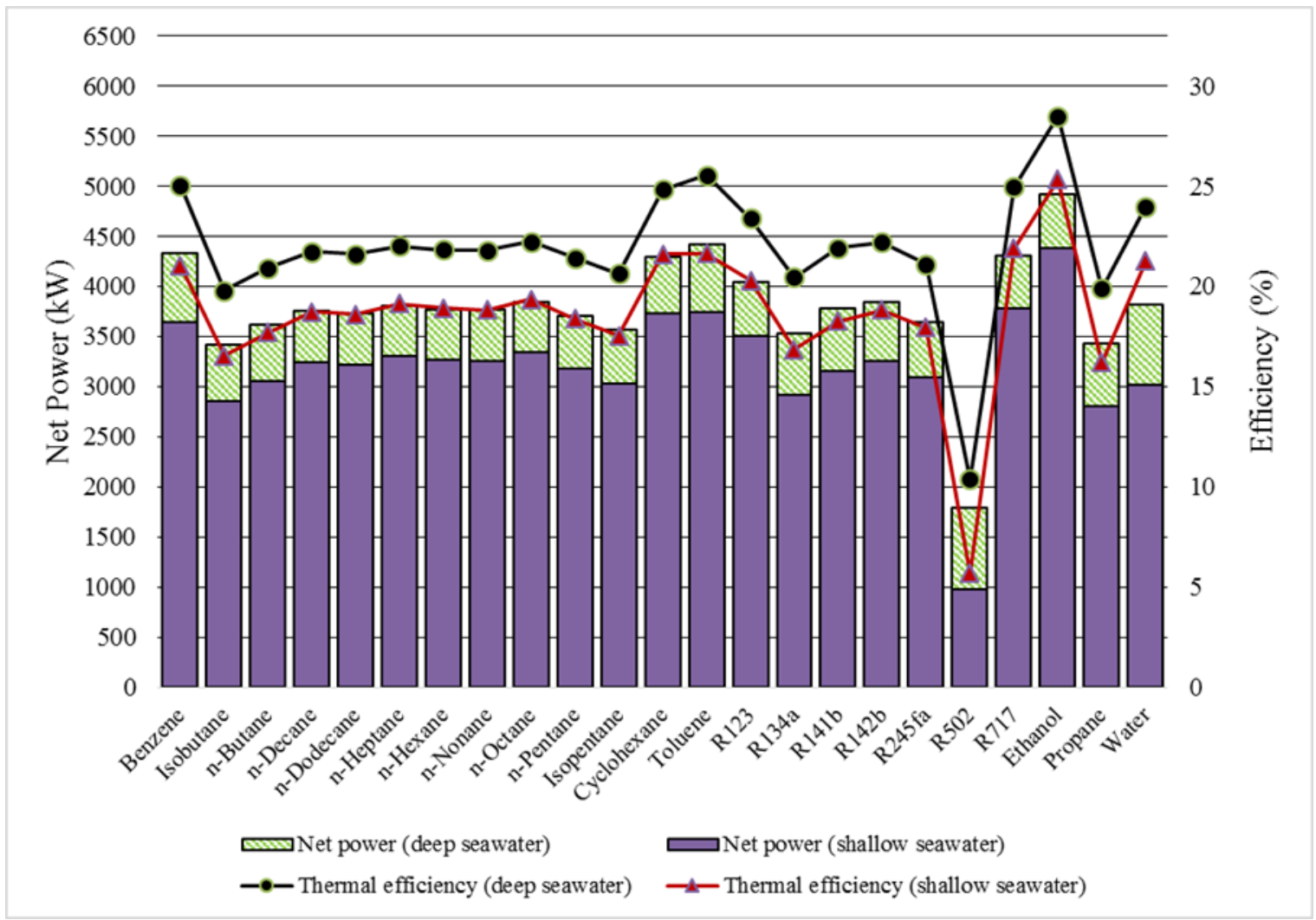

Figure 5. Comparison between deep and shallow seawater cooled systems for NORC configuration. 


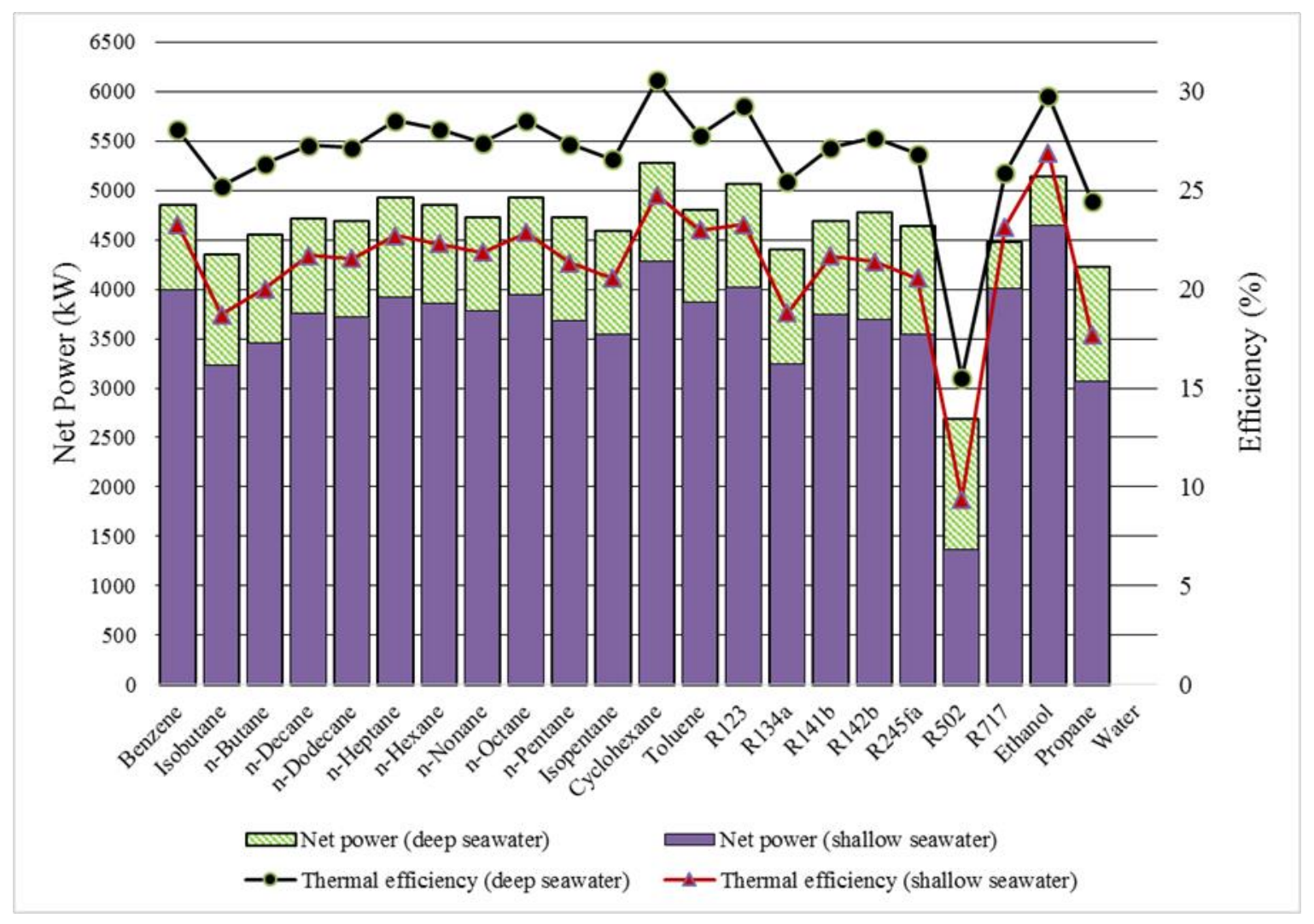

Figure 6. Comparison between deep and shallow seawater cooled systems for RORC configuration.

fluids show more potential for recuperation than others. For example, ethanol, which performed best in NORC simulation, was surpassed in RORC due to the high contribution in net power that recuperation provided to cyclohexane $(994 \mathrm{~kW}$ against $218 \mathrm{~kW})$. The highest relative contribution in net power comes from R502 (49.4\%), and lowest from R717 (3.6\%). Besides R502, wet fluids were less influenced by recuperation. This is expected as cycles operating with dry fluids (and isentropic to a lesser extent) have a characteristic high energy available at the expander outlet $[35,36]$. The increment in efficiency provided by recuperation is consistent with the literature [37, 38]. Higher efficiency means that a high power output can be maintained for a decreased heat input to the ORC [38]. In this work, the heat input was not necessarily decreased from NORC to RORC, which lead to higher values for both efficiency and net power output under RORC configuration.

\subsection{Shallow Seawater and Carnot Comparison}

In order to evaluate the benefit of using deep sea water, comparisons with the use of shallow seawater are exposed in Figures 5 and 6.

It is noticeable that the proposed deep cooled water system performs better than a standard seawater cooled one. Deep cooled systems had an average increment of net power output of $20.4 \%$ and $29.5 \%$ for NORC and RORC configurations, respectively. Thermal efficiency relative raise, in average, corresponds to $19.8 \%$ (NORC) and $27.9 \%$ (RORC), which is remarkable. The optimal NORC, with ethanol, presented $12.5 \%$ relative increment on thermal efficiency and net power output (from $4380 \mathrm{~kW}$ to $4926 \mathrm{~kW}$ ) while optimal cyclohexane RORC, showed an increment of $23.3 \%$ on both variables, with net power output raising from $4284 \mathrm{~kW}$ to $5283 \mathrm{~kW}$. Water NORC had $12.8 \%$ relative raise on efficiency and $26.8 \%$ on net power output. The most affected system was R502 RORC, which faced 96.6\% increment on net power output and $65.6 \%$ on thermal efficiency.

As the temperatures of heat absorption and rejection are not constant, Carnot efficiency $\eta_{\text {carnot }}$ must be calculated from average values. It slightly changes with the selected fluid due to the open constraints in the heating and cooling system. For cyclohexane NORC, Carnot efficiency is $41.6 \%$, giving a relative efficiency $\left(\eta_{\text {tot }} / \eta_{\text {carnot }}\right)$ of $73.5 \%$. For ethanol RORC, $\eta_{\text {carnot }}$ is $41.7 \%$, with relative efficiency of $68.4 \%$.

Gas turbines are the most used technology to generate power in Brazilian FPSOs [25] and the heat rate of these turbines is around $9300 \mathrm{~kJ} / \mathrm{kWh}$ [39]. Since the cost of the natural gas produced by the FPSOs, which is also consumed by the gas turbines, must be lower than resellers price (0.02966 Euro/kWh [40]), it is possible to calculate a limiting cost for the electricity produced by the ORC of 0.077 Euro $/ \mathrm{kWh}$. If the ORC electricity cost is higher than 0.077 Euro/kWh it will preferable to generate it by burning natural gas in gas turbines.

\section{Conclusions}

A deep seawater cooled ORC for waste heat recovery on FPSO was proposed in this paper in two configurations: non-recuperative (NORC) and recuperative (RORC). Optimizations with several organic fluid candidates were conducted under a Genetic Algorithm, in order to obtain maximized net power output by searching for the optimal expander inlet temperature and pressure. The optimal indicated NORC fluid was ethanol $(4926 \mathrm{~kW}$ net power output) while cyclohexane performed best under RORC $(5283 \mathrm{~kW})$. Recuperation contributed for higher efficiency and net power output in all applied cases with an average value of $22.7 \%$; moreover, it tended to reduce optimal expander inlet pressure and temperature. Those results can be understood together with another pattern: Recuperation 
allowed a higher working fluid mass flow rate, which contributes to higher absolute net power output.

When compared with shallow water cooled systems, the proposed system performed significantly better. The use of deep water raised net power output and thermal efficiency in all cases. For the optimal deep cooled configurations, it increases net power output by $23.3 \%$ (cyclohexane RORC) and $12.5 \%$ (ethanol NORC). The average contribution in power output from deep water use was $20.4 \%$ and $29.5 \%$ for NORC and RORC, respectively. Its average contribution on efficiency was $19.8 \%$ (NORC) and $27.9 \%$ (RORC)

The results presented in this work indicate how deep water cooled ORC for FPSO applications would behave from a thermodynamic point of view. It points that this configuration can be interesting from the same thermodynamic perspective. Future works on this matter may explore thermo-economical evaluations.

\section{Acknowledgements}

The third author of this paper would like to thank National Research Council, CNPq grants 306033/2012-7.

\section{Nomenclature}

c specific heat, $\mathrm{kJ} /(\mathrm{kg} \mathrm{K})$

$D$ pipe diameter, $\mathrm{m}$

f friction factor

g gravitational acceleration, $\mathrm{m} / \mathrm{s}^{2}$

$h$ enthalpy, $\mathrm{kJ} /(\mathrm{kg} \mathrm{K})$

$L \quad$ pipe length, $\mathrm{m}$

$\dot{m}$ mass flow rate, $\mathrm{kg} / \mathrm{s}$

$P$ pressure, $\mathrm{kPa}$

$\dot{Q}$ heat, $\mathrm{kW}$

$T$ temperature, ${ }^{\circ} \mathrm{C}$

$v$ flow velocity, $\mathrm{m} / \mathrm{s}$

$\dot{W}$ power, kW

Greek symbols

$\Delta \quad$ absolute variation

$\eta \quad$ efficiency

$\varepsilon \quad$ heat exchanger effectiveness

$\rho$ density, $\mathrm{kg} / \mathrm{m}^{3}$

Subscripts and superscripts

$\begin{array}{ll}\begin{array}{l}\text { carnot } \\ \text { crit }\end{array} & \begin{array}{l}\text { Carnot } \\ \text { critical } \\ \text { cw }\end{array} \\ \text { dsw } & \text { cooling water } \\ \text { deep seawater } \\ \text { ise } & \text { exhaust gases } \\ \text { l } & \text { isentropic } \\ \text { net } & \text { loss } \\ \mathrm{P} & \text { net } \\ \text { p } & \text { at constant pressure } \\ \mathrm{r} & \text { pump } \\ \text { ssw } & \text { recuperator } \\ \mathrm{t} & \text { shallow seawater } \\ \mathrm{wf} & \text { turbine } \\ & \text { working fluid }\end{array}$

\section{References:}

[1] Ministério da Ciência, Tecnologia e Inovação. Estimativas Anuais de Emissões de Gases de Efeito Estufa no Brasil [Annual Estimates of Greenhouse Gas Emissions in Brazil]. 2a Edição [2nd Edition]; 2014. [In portuguese].
[2] Statistisk sentralbyrå. Emissions of greenhouse gases, 1990-2014, final figures $\quad-$ Available at <http://www.ssb.no/en/natur-ogmiljo/statistikker/klimagassn/aar-endelige/2015-12-18> [accessed 3.2.2016].

[3] M. Absi Halabi, A. Al-Qattan, A. Al-Otaibi, "Application of solar energy in the oil industry - Current status and future prospects," Renewable and Sustainable Energy Reviews, 43, 296-314 2014.

[4] T.-V. Nguyen, M. Voldsund, B. Elmegaard, I. S. Ertesvåg, S. Kjelstrup, "On the definition of exergy efficiencies for petroleum systems: Application to offshore oil and gas processing," Energy, 73, 264-281, 2014a.

[5] S. De Oliveira, M. Van Hombeeck, "Exergy analysis of petroleum separation processes in offshore platforms," Energy Conversion and Management, doi:10.1016/S0196-8904(96)00219-1.

[6] T.-V. Nguyen, T. G. Fülöp, P. Breuhaus, B. Elmegaard, "Life performance of oil and gas platforms: Site integration and thermodynamic evaluation," Energy, 73, 282-301, 2014b.

[7] T.-V. Nguyen, L. Pierobon, B. Elmegaard, F. Haglind, P. Breuhaus, \& M. Voldsund, "Exergetic assessment of energy systems on North Sea oil and gas platforms," Energy, doi:10.1016/j.energy.2013.03.011.

[8] M. Voldsund, T. Nguyen, B. Elmegaard, I. S. Ertesvåg, "Exergy destruction and losses on four North Sea offshore platforms : A comparative study of the oil and gas processing plants," Energy, doi:10.1016/j.energy.2014.02. 080.

[9] M. Voldsund, I. S. Ertesvåg, W. He, S. Kjelstrup, "Exergy analysis of the oil and gas processing on a North Sea oil platform a real production day," Energy, doi:10.1016/j.energy.2013.02.038.

[10] B. M. Mazetto, J. A. M. Silva, S. Oliveira, “Are ORCs a good option for waste heat recovery in a petroleum refinery?" International Journal of ThermodynamicsIJoT, doi:10.5541/ijot.5000070476.

[11] L. Pierobon, T.-V. Nguyen, U. Larsen, F. Haglind, B. Elmegaard, "Multi-objective optimization of organic Rankine cycles for waste heat recovery: Application in an offshore platform," Energy, doi:10.1016/j.energy.2013.05.039.

[12] M.-H. Yang, R.-H. Yeh, “Analyzing the optimization of an organic Rankine cycle system for recovering waste heat from a large marine engine containing a cooling water system," Energy Conversion and Management, doi:10.1016/j.enconman.2014.09.044.

[13] M.-H. Yang, R.-H. Yeh, "Thermodynamic and economic performances optimization of an organic Rankine cycle system utilizing exhaust gas of a large marine diesel engine," Applied Energy, doi:10.1016/j.apenergy.2015.03. 083.

[14] J. E. Barrera, E. Bazzo, E. Kami, "Exergy analysis and energy improvement of a Brazilian floating oil platform using Organic Rankine Cycles," Energy, doi:10.1016/j.energy.2015.03.091.

[15] S. Glover, R. Douglas, M. De Rosa, X. Zhang, L. 
Glover, "Simulation of a multiple heat source supercritical ORC (Organic Rankine Cycle) for vehicle waste heat recovery," Energy, http://doi.org/10.1016/j.energy. 2015.10.004.

[16] G. Kosmadakis, D. Manolakos, G. Papadakis, "Experimental investigation of a low-temperature organic Rankine cycle (ORC) engine under variable heat input operating at both subcritical and supercritical conditions," Applied Thermal Engineering, http://doi.org/10.1016/j.applthermaleng. 2015.09.082.

[17] V. L. Le, M. Feidt, A. Kheiri, S. Pelloux-prayer, "Performance optimization of low-temperature power generation by supercritical ORCs (organic Rankine cycles) using low GWP (global warming potential) working fluids," Energy, http://doi.org/10.1016/j.energy.2013.12 027

[18] A. Desideri, S. Gusev, M. Van Den Broek, V. Lemort, "Experimental comparison of organic fluids for low temperature ORC (organic Rankine cycle) systems for waste heat recovery applications," Energy, http://doi.org/10. 1016/j.energy.2015.12.012.

[19] P. K. Takahashi, A. Trenka, "Ocean thermal energy conversion: Its promise as a total resource system," Energy, doi:10.1016/0360-5442(92)90073-9.

[20] W. H. Avery, C. Wu, Renewable energy from the oceans: a guide to OTEC, OXFORD UNIVERSITY PRESS. 1994. p. 1.

[21] H. Semmari, D. Stitou, S. Mauran, "A novel Carnotbased cycle for ocean thermal energy conversion," Energy, doi:10.1016/j.energy.2012.04.017.

[22] H. Yuan, N. Mei, P. Zhou, "Performance analysis of an absorption power cycle for ocean thermal energy conversion," Energy Conversion and Management, doi:10.1016/j.enconman.2014.07.015.

[23] M.-H. Yang, R.-H. Yeh, "Analysis of optimization in an OTEC plant using organic Rankine cycle," Renewable Energy, doi:10.1016/j.renene.2014.01. 029.

[24] J. Brandsar, (2012). Offshore Rankine Cycles (MSc Thesis). Trondheim, Norway. Norwegian University of Science and Technology.

[25] J. A. M. Pereira, J. D. De Jesus, E. A. De Carvalho, "Caracterização Dos Sistemas De Geração Elétrica dos FPSOs em Operação no Brasil [Characterization of Eletric Generation Systems of FPSOs in Brazil]," ENGEVISTA, 17, 433-443, 2015. [In Portuguese].

[26] L. Pierobon, T.-V. Nguyen, U. Larsen, F. Haglind, "Optimization of Organic Rankine Cycles for Off-shore Applications," in Proceedings of ASME Turbo Expo 2013. San Antonio, USA.

[27] PETROBRAS. Petrobras - Fatos e dados - Nove plataformas que vão ampliar a produção de petróleo no Brasil [Petrobras - Facts and data - Nine platforms that will increase the production of oil in Brazil] Available at <http://www.petrobras.com.br/fatos-edados/nove-plataformas-que-vao-ampliar-a-producaode-petroleo-no-brasil.htm> [accessed 3.2.2016]. [In Portuguese].

[28] MarineBio Conservation Society. The Ocean and
Temperature - MarineBio.org - Available at $<$ http://marinebio.org/oceans/temperature/> [accessed 6.3.2015].

[29] W. L. M. Neto (2015), Estudo do desempenho de um sistema de resfriamento de ar de alimentação de turbinas a gás para aplicação offshore utilizando água do mar [Study of the performance of a gas turbine cooling air supply system for offshore applications using sea water] (bachelor thesis). Salvador, Brazil. Federal University of Bahia. [In Portuguese].

[30] T. S. Metcalfe, P. Charbonneau, "Stellar Structure Modeling using a Parallel Genetic Algorithm for Objective Global Optimization," doi:10.1016/S00219991(02)00053-0.

[31] Klein. Engineering Equation Solver (EES), Academic Professional V9.901, 2015.

[32] C. Kalra, G. Becquin, J. Jackson, A. L. Laursen, H. Chen, K. Myers, H. Klockow, J. Zia, "High-potential working fluids and cycle concepts for next- generation binary organic rankine cycle for enhanced geothermal systems," In Thirty-Seventh Workshop on Geothermal Reservoir Engineering, 2012. Stanford, USA.

[33] A. Schuster, S. Karellas, R. Aumann, "Efficiency optimization potential in supercritical Organic Rankine Cycles," http://doi.org/10.1016/j.energy.2009.06.019.

[34] C. R. Nelson, "Application of Refrigerant Working Fluids for Mobile Organic Rankine Cycles," 3rd International Seminar on ORC Power Systems, Brussels, Belgium, 2015.

[35] F. J. Fernández, M. M. Prieto, I. Suárez, "Thermodynamic analysis of high-temperature regenerative organic Rankine cycles using siloxanes as working fluids," Energy, 36, 5239-5249, 2011. doi:10.1016/j.energy.2011.06.028.

[36] Y. Dai, J. Wang, L. Gao, "Parametric optimization and comparative study of organic Rankine cycle (ORC) for low grade waste heat recovery," Energy Conversion and Management, doi:10.1016/j.enconman.2008.10.018.

[37] B. Saleh, G. Koglbauer, M. Wendland, J. Fischer, "Working fluids for low-temperature organic Rankine cycles," Energy, doi.org/10.1016/j.energy.2006.07.001.

[38] S. Lecompte, H. Huisseune, M. Van Den Broek, B. Vanslambrouck, M. De Paepe, "Review of organic Rankine cycle (ORC) architectures for waste heat recovery," Renewable and Sustainable Energy Reviews, http://doi.org/10.1016/j.rser.2015.03.089.

[39] Siemens AG. Industrial RB211 Gas Turbines Available at < http://sie.ag/2tJvWjT $>$ [accessed 26.7.2017].

[40] Bahia Gás. Gás Natural - Tabela Tarifária [Natural Gas - Tax Table] - Available at < http://www.bahiagas.com.br/gas-natural/tabelatarifaria/> [accessed 26.7.2017]. [In Portuguese]. 